\title{
Comparative Studies of the Nutritional Value of Digitaria Iburua and Digitaria Exilis Seed Oils
}

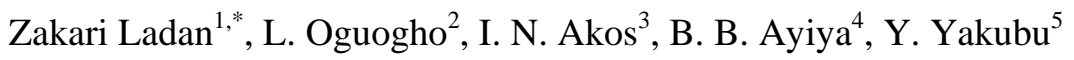 \\ ${ }^{1}$ Department of Chemistry, Kaduna State University, \\ Kaduna State, Nigeria. \\ ${ }^{2}$ Department of Chemistry, Kaduna State University, \\ Kaduna State, Nigeria. \\ ${ }^{3}$ School of Science Laboratory Technology, \\ The Federal Polytechnic, Kaura- Namoda, \\ Zamfara State, Nigeria. \\ ${ }^{4}$ Department of Chemistry, University of Auckland, Auckland 1142, \\ New Zealand. \\ ${ }^{5}$ Department of Chemistry, Kaduna State University, \\ Kaduna State, Nigeria. \\ *Corresponding author's email: zakariladan [AT] gmail.com
}

\begin{abstract}
The oil content of brown and white acha seeds was extracted and characterized using the AOAC procedure. Consumption of these grains by people with health-related diseases necessitated this study to authenticate its nutritional values. The physicochemical characterization revealed the two oils to have low oil yields of high quality. Biochemical profiling of the seeds showed that both oils have high concentration of polyunsaturated fatty acids, vitamins $\boldsymbol{A}$ and $E$ and other minor constituents. These results indicate that brown and white acha seeds are excellent sources of healthy nutrients to humans.
\end{abstract}

Keywords--- Digitaria iburua, Digitaria exillis, fatty acid methyl ester, GC-MS, Physicochemical properties

\section{INTRODUCTION}

Brown acha (Digitaria iburua) and white acha (Digitaria exilis) are annual cereal crops indigenous to West Africa. Acha, also known as Hungry rice is generally classified as millet and is cultivated for their straw and edible grains. The two

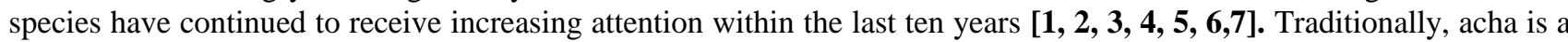
useful diet for diabetic people and for women after delivery [8]. It is rich in carbohydrate, serving as a good source of energy. The carbohydrate, protein and fat profile of acha can be closely compared to that of Sorghum. Acha grains also supply the body with good quantity of Vitamin B and minerals like calcium, iron and phosphorus. It offers good quantity of amino acids as nearly $10 \%$ of the cereal by weight comprises of protein. Kaduna state is located at the Northern part of Nigeria's high plains. The vegetation cover is Sudan Savannah type, characterized by scattered short trees, shrubs and grasses. Soil type is mostly loamy to sandy type. Substantial amount of clay is also found. The southern Kaduna weather favors the cultivation of crops such as ginger, tubers, millet, sorghum, rice, Digitaria species and many more. Despite the large cultivation of digitaria species in the southern part of Kaduna state, Nigeria, there is little comprehensive data on the two varieties [9]. There are reports in the literature on the potentials of this grain as a non-conventional cereal grain. The present study presents the nutritional benefits of two Digitaria species grown and commonly consumed in southern part of Kaduna state.

\section{EXPERIMENTAL}

\subsection{Materials}

The brown and white acha seeds were purchased from Central Market, Kaduna, Nigeria. HPLC grade organic solvents were purchased from Fluka \& Aldrich Chemicals Limited and were used without further purification.

\section{Methods}

The brown and white acha seeds were processed by removing the dirt and then dried in a shade for one week at $25^{\circ} \mathrm{C}$. The dried seeds were pulverized into powder using pestle and mortar. $600 \mathrm{~g}$ of each sample of brown and white 
acha was weighed into a filter paper and carefully folded. The folded content was placed into the thimble of the soxhlet apparatus fitted with a condenser. $500 \mathrm{~cm}^{3}$ of hexane contained in a round bottomed flask was fitted to the apparatus. Extraction under reflux was carried out for $6 \mathrm{~h}$ after which the extract was concentrated using rotatory evaporator. The oil was dried on a water bath at $50^{\circ} \mathrm{C}$ until all the residual hexane completely evaporated. The dried oil was cooled and then weighed to obtain the yield in grams. The process was repeated in triplicate several times until enough oil was obtained for the physicochemical and GC-MS analyses.

\subsection{Physicochemical analysis}

The physicochemical properties i.e. refractive index, specific gravity, color, iodine value, saponification value, acid value, free fatty acid value and peroxide value were determined using standard procedures [10]. Tocopherol and Vitamin A were determined using [11] and [12] methods.

\subsection{Preparation of the fatty acids}

The oil was converted to fatty acid methyl esters (FAME) using the potassium hydroxide/methanol method [13]. Briefly, $4 \mathrm{~g}$ of the extracted oil was transferred to a round-bottomed flask containing boiling chips and $40 \mathrm{~cm}^{3}$ of methanol and $0.5 \mathrm{~cm}^{3}$ of potassium hydroxide solution were added to the flask. The content was refluxed until it became clear and was transferred into a separation funnel. $40 \mathrm{~cm}^{3}$ of distilled water was added, shaken and allowed to separate. $20 \mathrm{~cm}^{3}$ heptane was added to extract the esters formed. Another portion of $20 \mathrm{~cm}^{3}$ heptane was added again, shaken and the organic layer separated. The two extracts were combined and washed with $20 \mathrm{~cm}^{3}$ portion of water and separated. The ester extract was dried over anhydrous sodium sulphate and evaporated to approximately $10 \mathrm{~cm}^{3}$ ready for the GCMS analysis.

\subsubsection{Analysis of the fatty acid using GC-MS}

Fatty acid methyl esters of the oils were analyzed by GC-MS using Shimadzu QP2010 Series. The following analytical conditions were adopted: Column; Cross-linked 5\% phenyl methyl silicone (DB-WAX:30 m x $0.25 \times 0.25$ $\mu \mathrm{m})$. Carrier gas; Helium at flow rate $0.90 \mathrm{Ml} / \mathrm{min}$, injector temperature programmed was $100^{\circ} \mathrm{C}$ for $2 \mathrm{~min}$, then increased to $190^{\circ} \mathrm{C}$ at $4^{\circ} \mathrm{C} / \mathrm{min}$.

The identification of the fatty acids was achieved by retention times when compared with authentic standards analyzed under the same conditions while the relative percentages of each fatty acid was determined based on peak area measurements.

\section{RESULTS AND DISCUSSION}

Table 1 shows the physicochemical properties and percentage yields of the oil extracted from the two acha species. The brown acha had $3.14 \%$ yields while the white acha had $2.67 \%$ yields. These percentage yields are within the range of 2-9\% as estimated by the National Research Council, NRC $[\mathbf{1 4}, \mathbf{1 5}]$. This yield is low when compared with other oil seeds such as soybean oil (14.51\%), groundnut oil $(10.54 \%)$ and maize $(6.63 \%)$.

The saponification values for brown and white acha oils are $191.1 \mathrm{mgKOH} / \mathrm{g}$ and $170.1 \mathrm{mgKOH} / \mathrm{g}$ respectively. These values are within the accepted values of $150 \mathrm{mgKOH} / \mathrm{g}-350 \mathrm{mgKOH} / \mathrm{g}$ for oils used in soap making. This implies that if reasonable quantity of the oils can be obtained from the acha seeds, it will be good for soap production.

The acid values for brown and white acha oils were found to be $3.0 \mathrm{mgKOH} / \mathrm{g}$ and $4.1 \mathrm{mgKOH} / \mathrm{g}$ respectively. This is an indication that the oils are stable at room temperature as such not susceptible to rancidity. A similar finding has been reported [16].

The iodine values for the brown and white acha oil were found to be $98.2 \mathrm{gI}_{2} / 100 \mathrm{~g}$ and $88.8 \mathrm{gI}_{2} / 100 \mathrm{~g}$ respectively. This suggests that the oils are free flowing, non-drying and unsaturated. Iodine value is a measure of the relative degree of unsaturation in oils. The greater the iodine values the higher the susceptibility to oxidation. This result concurs with previous studies that suggests that prolong storage of the oils may lead to rancidity $[\mathbf{1 7}, \mathbf{1 8}]$.

The peroxide values for the brown and white acha oil are $8.10 \mathrm{meqH}_{2} \mathrm{O}_{2}$ and $9.30 \mathrm{meqH}_{2} \mathrm{O}_{2}$. These values are low when compared with oil seeds of Balanites aegyptica $(22.50 \mathrm{meq} / \mathrm{Kg})$, Ximenia Americana $(29.40 \mathrm{meq} / \mathrm{Kg})$ and Lophira lanceolate $(31.20 \mathrm{meq} / \mathrm{Kg})$. The low peroxide values are indications that the oils will be more stable to oxidative degradation.

The peroxide values for the brown and white acha oil were 8.10 meqH $\mathrm{O}_{2}$ and $9.30 \mathrm{meqH}_{2} \mathrm{O}_{2}$, respectively. These values are low when compared with oil seeds of Balanites aegyptica $(22.50 \mathrm{meq} / \mathrm{Kg})$, Ximenia Americana $(29.40 \mathrm{meq} / \mathrm{Kg})$ and Lophira lanceolate $(31.20 \mathrm{meq} / \mathrm{Kg})[14]$. The low peroxide values are indications that the oils will be more stable to oxidative degradation.

With $6.150 \mathrm{mg} / \mathrm{ml}$ and $5.071 \mathrm{mg} / \mathrm{ml}$ vitamin A content in brown and white acha seed oils, respectively, the seeds are an excellent source of this nutrient. Compared to other seed oils [12], this is a significant quantity of vitamin A. In view of this, the oils can be used as supplementary diets to improve vision, growth and development, maintenance of immune system as reported by other researchers $[\mathbf{1 9 , 2 0}]$. For vitamin E, the brown acha oil had a concentration of 17.765 IU/I, while the white acha had 12.316 IU/I of the nutrient. The two acha species appear to be a good source of vitamin E, providing levels within the recommended daily intake values of 5.5-17 IU/I for adults and 3-18.4 UI/I for children 
$[\mathbf{2 0 , 2 1}]$. Vitamin $\mathrm{E}$ has been reported to be a powerful antioxidant, acting as a peroxyl radical to prevent the propagation of free radicals in tissues [22]

The specific gravity of the brown and white acha oils was 0.9252 and 0.9236 respectively. It has been reported that the specific gravity of naturally occurring fats and oils is less than 1.0 [16] This revealed the purity of the oils which are free from water and other impurities.

The refractive indexes of the brown and white acha oils were 1.4923 and 1.4913 respectively. This indicates that the oils are comparatively pure.

Table 1: Physicochemical properties of extracted acha oils

\begin{tabular}{|l|l|l|l|}
\hline S/N & Parameter & Brown acha oil & White acha oil \\
\hline 1 & Lipid content, \% & 3.14 & 2.67 \\
\hline 2 & Saponification value $(\mathrm{mgKOH} / \mathrm{g})$ & 191 & 170 \\
\hline 3 & Acid value $(\mathrm{mgKOH} / \mathrm{g})$ & 3.00 & 4.10 \\
\hline 4 & Iodine value $\left(\mathrm{I}_{2} / 100 \mathrm{~g}\right)$ & 98.20 & 88.80 \\
\hline 5 & Vitamin A $(\mathrm{mg} / \mathrm{ml})$ & 6.1500 & 5.0710 \\
\hline 6 & Vitamin E $(\mathrm{mg} / \mathrm{ml})$ & 17.7650 & 12.3160 \\
\hline 7 & Peroxide value $\left(\mathrm{meqH}_{2} \mathrm{O}_{2}\right)$ & 8.10 & 9.30 \\
\hline 8 & Color & Red & Light yellow \\
\hline 9 & Specific gravity @ $20^{\circ} \mathrm{C}$ & 0.9252 & 0.9236 \\
\hline 10 & Refractive Index & 1.4922 & 1.4913 \\
\hline
\end{tabular}

\section{SPECTROSCOPIC ANALYSIS}

Fig. 1 is the ultraviolet-visible spectra of white acha oil showing the maximum wavelength of absorption at 272 nm, while that of brown acha Fig 2 showed absorption bands at $251 \mathrm{~nm}$ and $267 \mathrm{~nm}$ respectively which indicate the presence of chromophores in the oil. This is usually associated with the presence of unsaturated groups having unshared pairs of electrons as reported [23].

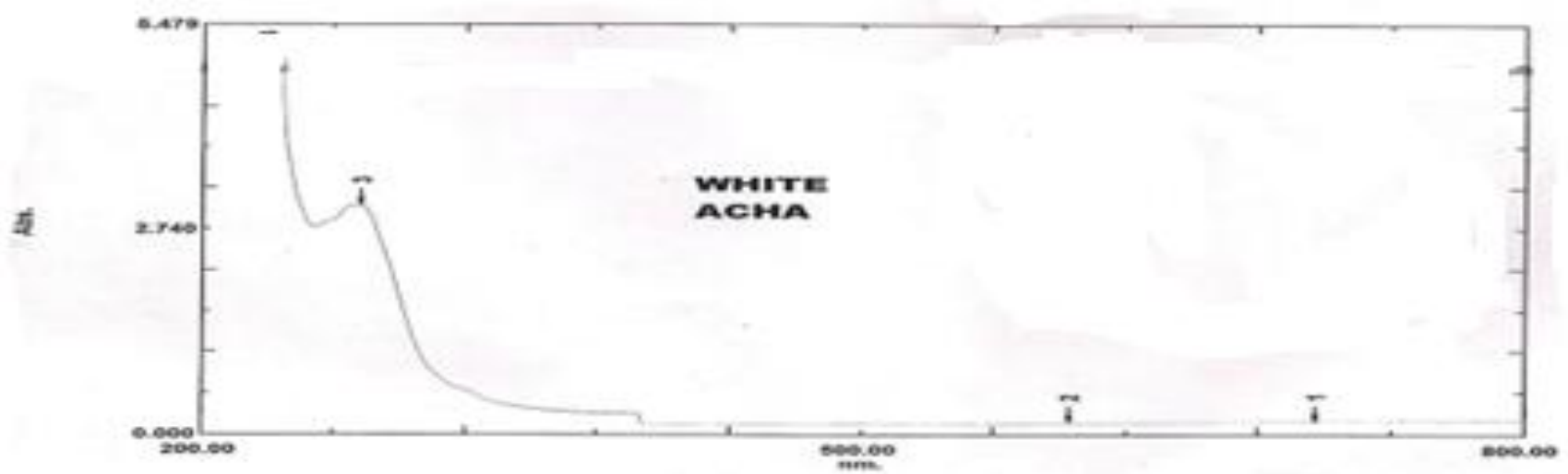

Fig 1: UV-VIS Absorption Spectrum of white acha oil 


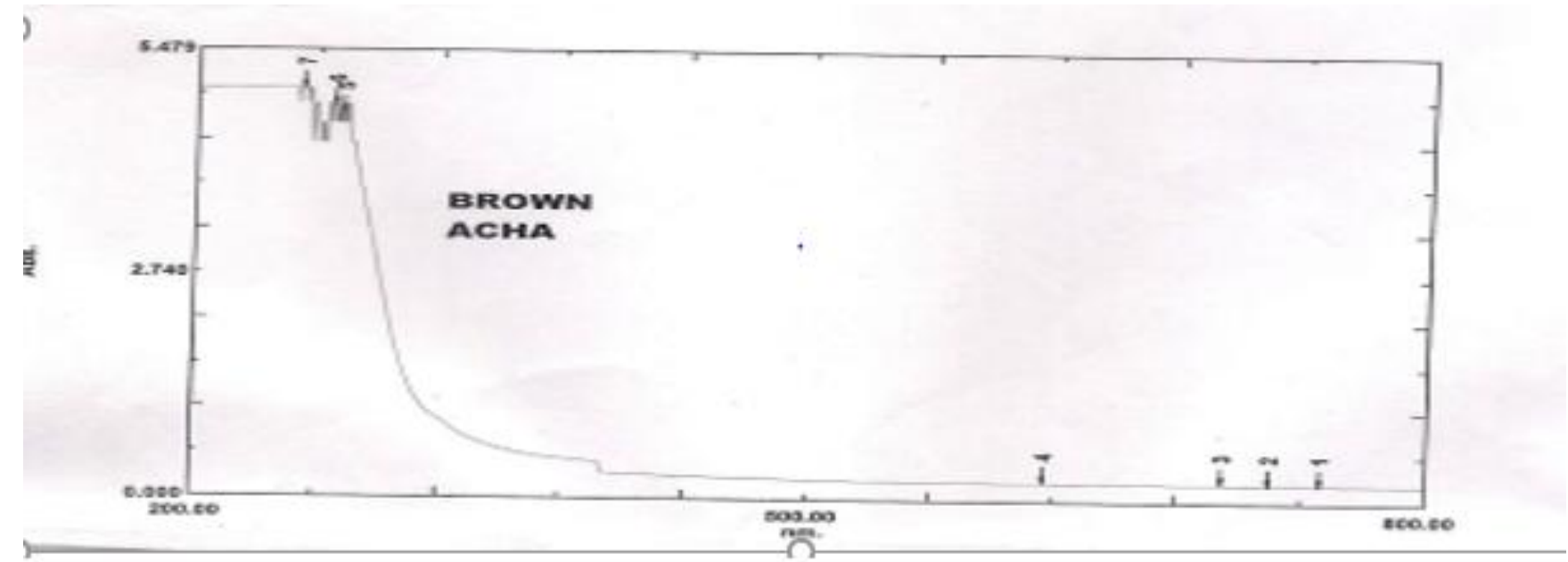

Fig.2: UV-VIS absorption spectrum of brown acha oil

The infrared absorption bands for the two oils showed three major similar absorption bands. At $3500 \mathrm{~cm}^{1}, \mathrm{O}^{-} \mathrm{H}_{\text {str }}$ for hydroxyl groups appeared. The carbonyl groups $\mathrm{C}=\mathrm{O}_{\text {str }}$ appeared at $1722.49 \mathrm{~cm}^{-1}$ while the $\mathrm{C}-\mathrm{H}_{\text {str }}$ for saturated alkanes appeared at $2929.98 \mathrm{~cm}^{-1}$. This is an indication that the oils contain long chain fatty acid containing long chain hydrocarbon and acidic functional groups [24].

Table 2 shows the percentage composition of the white and brown acha oil. The three major compounds in the white acha oil are $28.85 \%$ of octadec-11-enoic acid methyl ester, $24.04 \%$ of 9,12 - octadecadienoic acid methyl ester and $21.28 \%$ of pentedecanoic acid -1,4-methyl ester. Other minor constituents present were 5.84\% decane, $6.49 \%$ stearic acid methyl ester and $1.19 \%$ arachidic acid methyl ester. For the brown acha oil, four major fatty acids were present. They are $30.10 \%$ linoleic acid methyl ester, $20.56 \%$ oleic acid, $15.40 \%$ palmitic acid methyl ester and $18.34 \%$ Octadec-11-enoic acid methyl ester. Other minor constituents present in the brown acha seed oil are $7.59 \%$ palmitic acid, $4.92 \%$ stearic acid methyl ester, $1.59 \%$ stearic acid, $1.11 \%$ arachidic acid methyl ester and $0.39 \%$ heptacosanoic acid methyl ester.

The above results confirm that a good percentage of the oils are made up of unsaturated fatty acids as such will be healthy for human consumption. Reports by other researchers have shown that the unsaturated fatty acid are effective in lowering total cholesterol and low-density lipoprotein (LDL) cholesterol content in blood, control of cardiovascular diseases and regulation of several processes in the brain $[\mathbf{1 6}, \mathbf{2 5}, \mathbf{2 6}]$.

Table 2: Percentage composition of white and brown acha Oil

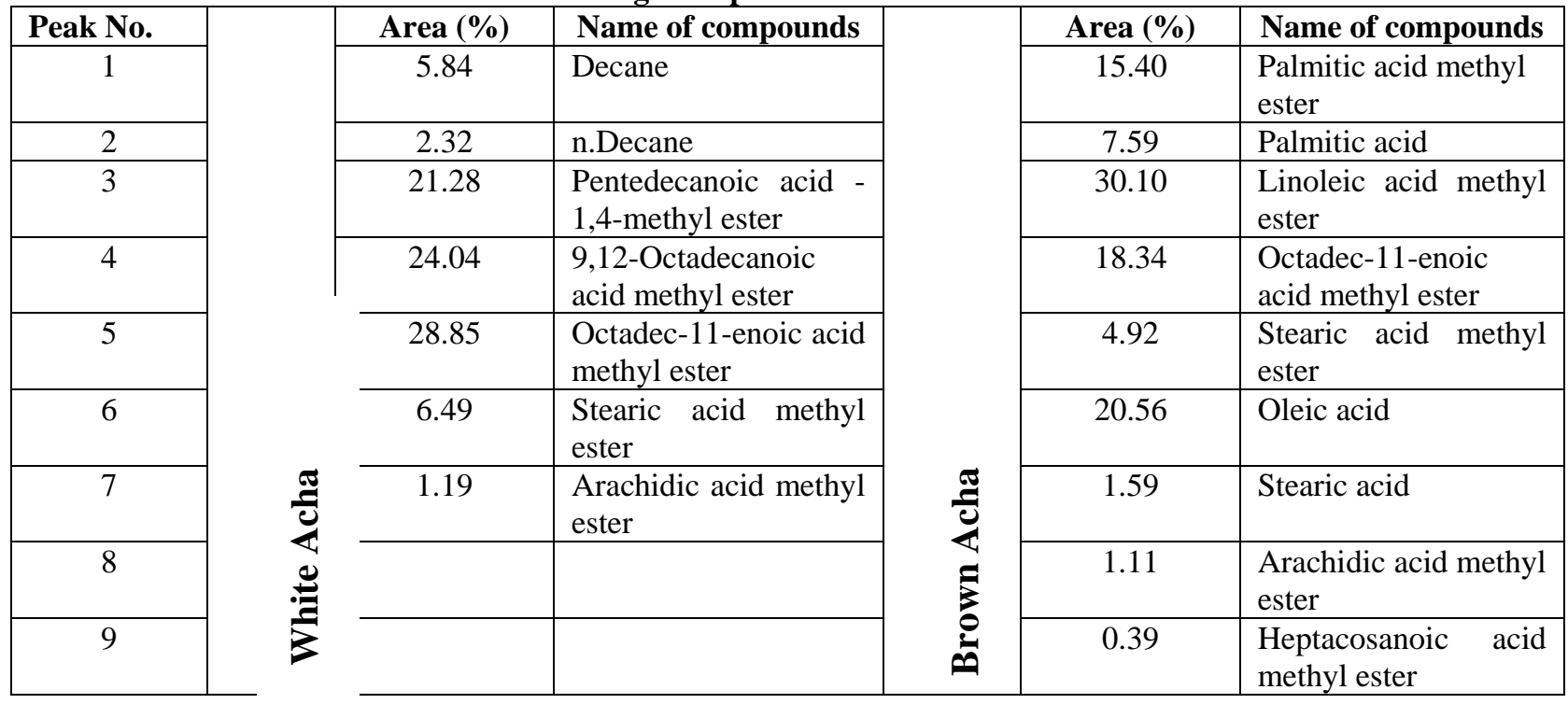




\section{CONCLUSION}

The fatty acids profiles of oils extracted from brown and white acha seeds had 98.61 and $84.40 \%$ proportions as polyunsaturated fatty acids, respectively. The physicochemical characteristics of the oils from both seeds revealed that they can improve the status of patients with heart related diseases, poor vision and brain disorders.

\section{REFERENCES}

[1]. Jideani IA, Owusu Apenten RK, Muller HG. Solubilisation and reductive alkylation of proteins from a tropical cereal Digitaria exilis Stapf -Acha. Nig. Food J. 18:1-11. 2000.

[2]. Mbithi-Mwikya S, van Camp J, Mamiro PR, Ooghe W , Kolsteren P, Huyghebaert A .Evaluation of the nutritional characteristics of a finger millet based complementary food. J. Agric. Food Chem. 50:3030-3036. 2002.

[3]. Morales-Payan JP, Ortiz JR, Cicero J, Taveras F. Digitaria exilisas a crop in the Dominican Republic. In: Janick J, Whipkey A (eds), Supplement to: Trends in new crops and new uses. ASHS press, Alexandra, VA. Pp. 120127. 2002.

[4]. Nzelibe HC, Nwasike CC. The brewing potential of 'acha' (Digitaria exilis) malt compared with pearl millet (Pennisetum typhoides) malts and sorghum (Sorghum bicolour) malts. J. Inst. Brew.101:345-350. 1995.

[5]. Adoukonou-Sagbadja H, Dansi A, Vodouhè R, Akpagana K. Indigenous knowledge and traditional conservation of fonio millet (Digitaria exilis, D. iburua) in Togo. Biodiver. Conserv. 15:2379-2395.2006.

[6]. Lasekan OO. Compounds contributing to the characteristic aroma of ibura mail (D. iburua Stapf) .Agric. Sci. Soc. Eng. Technol.(ASSET) 1:93-99. 2004.

[7]. Jideani IA. Digitaria exillis (acha/onio),Digitaria iburua (iburu/fonio) and Eluesine coracana (tamba/finger millet)-Non conventional cereal grains with potentials. Scientific Res. Essays, Vol.7(45):3834-3843. 2002.

[8]. Melissa M. The Health benefits of Fonio: The nutritious superfood, Atacora products pp1-10. https://www.atacora.com. Feb. 2017.

[9]. Duniya KP. Productivity of hungry rice (Digitaria exilis) in selected local government areas of kaduna state, Nigeria. M.Sc. Thesis, Ahmadu Bello University, Zaria. Kaduna State Nigeria. Pp 67-100.2014

[10]. AOAC Official methods of analysis, $17^{\text {th }}$ Edition. Association of official Agricultural Chemists. Washington DC, USA. Pp 89-160. 1997.

[11]. IUPAC. Standard methods for the analysis of oils, fats and derivatives, $6^{\text {th }}$ Edition, Pergamon press, Paris. Pp 126-138. 1979.

[12]. Pearson D. Pearson chemical analysis of foods. $8^{\text {th }}$ Edition. Longman Group Ltd., London. Pp 130-150. 1981.

[13]. Muniz MAP.Physicochemical characterization,fatty acid composition and thermal analysis of Bertholletia excelsa HBK oil. Pharmacogn. Mag. Jan-March 11(41):147-151. 2015.

[14]. NRC. Grains. Fonio (Acha), In: Lost crops of Africa, volume 1. National Academy Press, National Research Council Washington, DC, USA pp 59-75, ISBN 0-309-049903. 1996.

[15]. Bengaluru L. Ethiopian crop could save Indian farmers. The new Indian Express, pp. 23, 2017

[16]. Ladan Z, Okonkwo EM., Amupitan JO., Ladan EO, Aina B. Physicochemical properties and fatty acid profile of Hyptis spicigera seed oil. Res. Journ. Of Appl. Sc. 5(2):123-125. 2010.

[17]. Dhellot JRE, Matouba MG, Maloumbi JMN, and Ngoma DGS. Extraction, chemical composition and nutritional characterization of vegetable oils: Case of Amarantheus hybrdus (var 1\&2) of Congo. Afr. J. Biotechnol. 5:1095-1101. 2006.

[18]. Onuoha OG, Chibuzo E, Badau M. Studies on the potential of malted Digitaria exilis, Cyperus esculentus and Colocasia esculenta flour blends as weaning food formulation. Nig. Food J. Vol 32, Issue 2, 40-47, 2014. 
[19]. Ayo JA, Nkama I. Acha (Digitaria exilis) in West Africa. Int. J. Food Agric .1:129-144. 2006.

[20]. Aldofina R, Koroch H, Rodolfo J, James ES. Nutritional value of Fonio (Digitaria exilis) from Senegal: African Natural plant products Vol II: Discoveries \& Challenges in Chemistry, Health and Nutrition. Chapter 10, pp127133. ACS Symposium series. Vol 1127.2013

[21]. Tilley M. Novel methods for separation and characterisation of proteins from non-wheat cereals. Cereal Foods World Suppl. 54(4): A7. 2009.

[22]. Awika JM, Rooney LW. Sorghum phytochemicals and potential impact on human health. Phytochemistry . 65:1199-1221. 2004.

[23]. Skoog DA., Holler FJ., Crouch SR. Principles of instrumental analysis, $6^{\text {th }}$ Edition, Belmont CA, Thomson Brooks/Cole. Pp 169-173. 2007.

[24]. Dudley HW., Ian F. Spectroscopic Methods in Organic Chemistry. $5^{\text {th }}$ Ed., Tata McGraw-Hill Publishing Company Ltd, New Delhi, Pp.40-53. 2005.

[25]. Warldlaw GM., Snook JT. Effect of diets high in butter,corn oil or high oleic acid sunflower oil on serum lipids and Apo lipoproteins in men. Am. J. Clin. Nutr. 51:815-821. I

[26]. Contreras MA. \& Rapoport SI. Recent studies on interactions between $n=3$ and $n=6$ polyunsarurated fatty acids in brain and other tissues. Curr. Opin. Lipidol 13: 267-272. 2002. 


\section{Appendix 1}

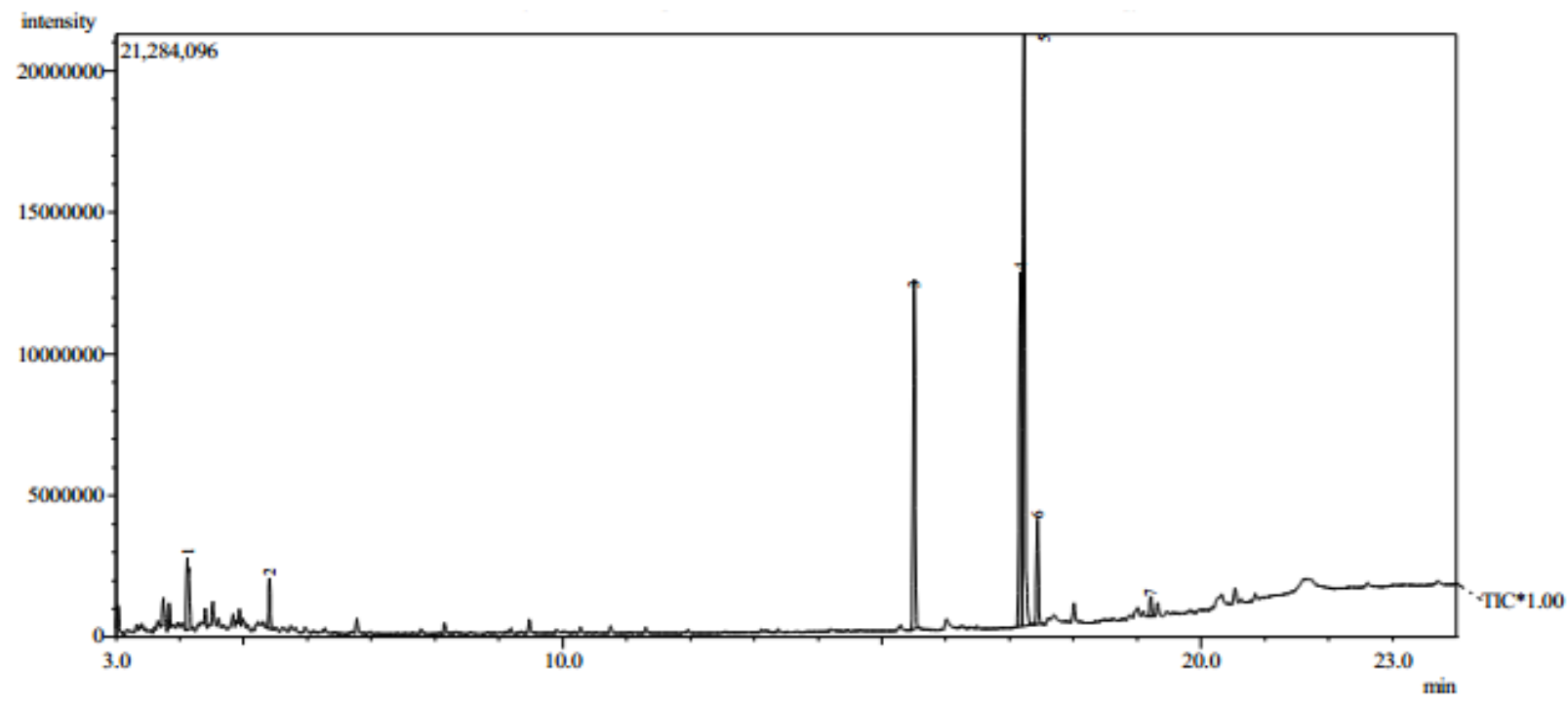

Fig. 3: GC profile of white acha oil

Appendix 2

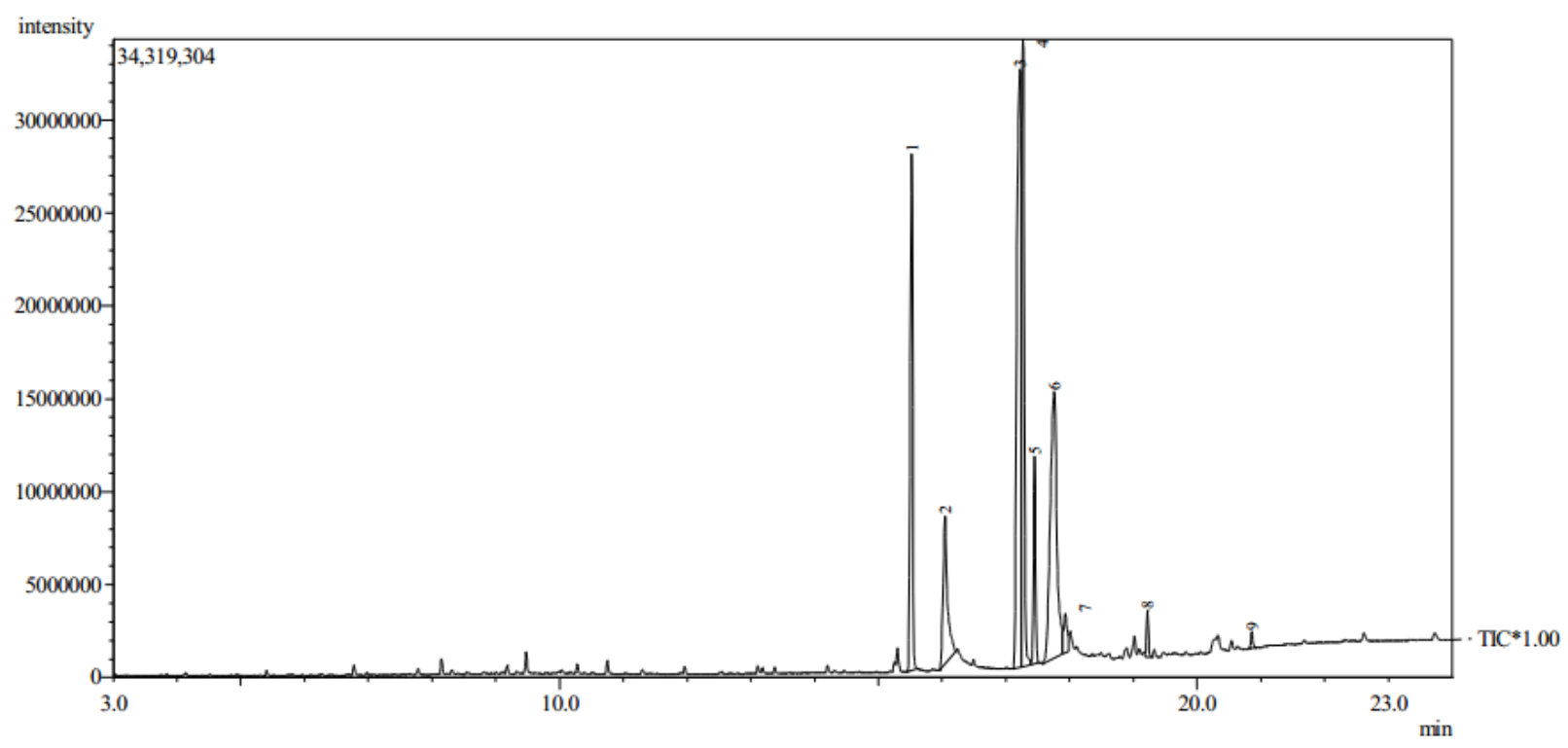

Fig. 4: GC profile of brown acha oil 